\title{
The transformation from traditional to commercial family farming
}

\author{
J. H. L. Joosten * \\ Department of Agricultural Economics of the Tropics and Subtropics, Agricultural \\ University, Wageningen, The Netherlands
}

Received 7 October, 1968

\section{Summary}

In this article the author emphasizes the central role the farmer and his family are playing in the process of agricultural development. In the transformation process from subsistence to commercial farming there is an increase in the number of factors influencing the decisions the farmer has to make. The farms are classified according to the proportion of gross product for the market. Through this classification a number of problems encountered by economists can be explained. Special attention is given to the relationships between farmsize and other factors such as the production per unit area, the number of consumer units per family, the welfare index, the costs of non-agricultural inputs. The impact on the portion of gross product that has to be sold is shown for an assumed growth of welfare and costs of nonagricultural inputs. Simple arithmetic reveals the crucial importance of expanding domestic or foreign markets for agricultural products. Finally future research in agrarian economics is considered. The need for farm management research, to anticipate farmers' problems and to keep them informed is stressed as are the aspects of infrastructure.

\section{Introduction}

In traditional farming the farmer takes his decisions with the knowledge and skills he has inherited from foregone generations. In general it was believed that this farming was static and that innovations were not introduced by the farmers nor that the farmer adjusted his operations to changing circumstances. This attitude would be common in the low-income farming of the tropics, generally called peasant farming.

The aim of these farmers was primarily the self-provision in food of the family. In addition to that he produced a little more, mainly for the local market, to cover his limited need for cash. He lived in a precapitalistic community.

Confrontation with traders, however, introduced and promoted production for the market (e.g. rubber, oilpalm products, coffee and cocoa) and foreign enterprises offered ways of earning additional cash. As he still needed little cash, he only bothered to sell products and or to work on the plantations to satisfy needs for cash.

Boeke (1953, p. 40) presented the resulting 'perverse supply curve' in the following

* I am indebted for critical remarks to H. A. Luning and H. J. Hoefman. 
way. "Anyone expecting western reactions will meet with frequent surprises when the price of coconut is high, the chances are that less of the commodities will be offered for sale; when wages are raised the manager of the estate risks that less work will be done; if 3 acres are enough to supply the needs of the households a cultivator will not till 6; when rubber prices fall the owner of a grove may decide to tap more intensively, whereas high prices may mean that he leaves a larger or smaller portion of his tappable trees untapped".

But Helleiner $(1966$, p. 9) showed that the peasant could substantially increase the production of these various agricultural crops while maintaining and perhaps even increasing output per capita of 'traditional' goods and services. These new opportunities were accepted by the farmer while making new decisions about the allocation of his resources, chiefly land and labour, for maximum welfare. By taking this decision, the peasant farmer in the tropics entered the transitional stage from subsistence to commercial farming, a development that ends with marketing almost the whole production and almost complete monetization of his farming. Few of these farmers have reached the commercial stage. They are still transitional. This determines his decisions on how to reorganize his farming, on which products he will grow and on what outside opportunities he will seize, to reap the greatest personal benefit as he understands it. More and more he becomes aware of costs, alternatives, prices of products, and of particular resources (Joosten, 1960; Bauer, 1948).

Based on the concept of increase in the percentage of production for the market which is a result of evolution of farming, I classify farms as follows:

1. Subsistence farms; very little trade, highly traditional.

2. Small scale peasant farms; little trade.

3. More developed peasant farms; much production for trade in relation to that for subsistence.

4. Middle-class commercial family farms, producing mainly for the market.

5. Large commercial family farms; fully monetized.

See also Miracle (1968) and Mellor (1968).

These concepts can explain some phenomena encountered in peasant farming, among others the pattern of farm sizes, perverted supply curves, competition between food production and cash-crop production, preferences between farming and leisure, wages of casual farm-labour, differences in the adoption or resistance to innovations.

\section{Size of peasant farms}

Several investigations in different parts of the tropics show that the distribution of farm sizes is similar.

The size of a subsistence farm depends on the production of food for the farm family. If so the size expressed in gross product will be:

Af $\times P \times R=C f \times D$

in which:

$A f=$ farm area in any unit

$P=$ production per unit area planted, expressed in units of the main food-crop

$R=$ the cropping rate; the number of plantings per year per unit area e.g. in shifting cultivation with one crop in ten years 0.10 , in permanent cultivation with one crop per year 1.0 and with two crops per year 2.0 
$C f=$ number of consumer units in the family including the servants

$D=$ the food consumption per consumption unit expressed in weight units of the main food crop, including seed, wastage and storage losses.

This formula does not allow exchange of products for goods and services within the farmers' community. He needs those goods and services and he must pay for them with products from his farm or with money acquired by selling a part of his produce. His gross product $(A f \times P \times R)$ must be enlarged by a factor which $\mathrm{I}$ have called the welfare index $(W)$.

$$
W=\frac{\text { gross product }}{\text { food consumption of the famil: }}=\frac{A f \times P \times R}{C f \times D}
$$

I think this increase is always possible in this stage of development and $I$ agree with Helleiner (1966, p. 10) who stated: "it appears that in this economy there exists a considerable (potential) 'agricultural surplus', consisting not only of unutilized lands (if land is abundant) but also of unutilized labor, which could be mobilized for the expansion of material output"; and further: "Their unemployment is not the result of their inability to raise material output with further increases in labor-inputs. Rather, it is the result of deficient demand for their material output."

Therefore:

Af $\times P \times R=C f \times D \times W$

so that farm size will be:

$$
A f=\frac{C f \times D \times W}{P \times R}
$$

In this formula $P$ and $D$ are expressed in physical units (e.g. rice); it can also be expressed in its monetary value, which is of course better if several kinds of products are involved and trade is no longer barter but monetary.

If so, $W=\frac{\text { total family budget }}{\text { money value of food consumption of the family }}$, as in the law of Engel.

Low prosperity goes with a high percentage of the family's expenditure on food, say $80 \%$ and the lower this percentage the higher the prosperity.

The formula shows that farm-size pattern (assuming comparable production techniques) is related to the size of the family. Further that in areas with limited landresources the farmer will increase his production by intensification, in other words by enlarging output per unit area. Here we encounter one of the first decisions of the farmer with a growing family namely more labour-intensive cultivation, with higher family labour input per unit of area or renting land and possibly hiring casual labour in busy periods. It also defines the phenomenon that in such areas the production per unit land is higher on farms with a high man/land ratio than on large farms with a lower man/land ratio (Tschajanov, 1923; Khusro, 1964; Bachman and Christensen, 1967).

Non-factor costs become involved and the farmer enters the transitional stage with further development towards stage 3 and towards the more commercial farms of 
stage 4 and ultimately 5 .

To pay for those inputs, especially if non-agricultural (exogeneous) inputs become involved the farmer must further increase his production if he wants to maintain or increase his prosperity.

The costs can also be expressed as an index, the cost-index $(\mathrm{Co})$, by which production must be multiplied if the farmer is to meet these costs. As prosperity increases, so will the welfare index $(W)$. To increase $W$ and to meet costs, a much higher gross production is therefore needed and the formula for farm size will be:

$A f=\frac{C f \times D \times W \times C o}{P \times R}$

In this formula $C o=\frac{\text { gross product }}{\text { net product }}$.

This factor will be 1.25 if the costs are $1 / 5$ of the gross product. If $C f \times D \times W$ in this formula is replaced by family budget $(I f)$ and savings are ignored, the general formula becomes:

$A f=\frac{I f \times C o}{P \times R}$

\section{Costs, prosperity and markets}

Helleiner (1966) and others underline that the prerequisite for expanding production is an expanding effective demand for farm products. If this growth in demand ceases, the farmers are soon overproducing (e.g. coffee) with low prices. The previous section shows that increase in welfare and in production by costly monetary inputs is possible only if there is a remunerative outlet for the produce. An expanding and smoothly running market is necessary. This influence is described by the following formula:

$T=\left(1-\frac{S}{W \times C o}\right) \quad 100 \%$

$T$ being the percentage of gross output sold

$$
\begin{aligned}
T=\frac{\text { sold products }}{\text { gross output }} \times 100 & =\frac{C f \times D \times W \times C o-C f \times D \times S}{C f \times D \times W \times C o}= \\
& =\left(1-\frac{S}{W \times C o}\right) 100
\end{aligned}
$$

$S$ stands for the percentage self-sufficiency in food, in other words the proportion of the family's food intake which is taken from the farm produce.

For example: assume $W=1.5, C o=1.25$ and $S=0.6$ then the farmer must sell $68 \%$ of his produce. Increasing $W$ to 2.00 and costs $(C o=1.30)$ and reducing the self-sufficiency to 0.5 will increase $T$ to about 80 . Lower $W, C o$ and $S$ will diminish it considerably. 
Higher costs and welfare, usually associated with specialization of production, result in less self-sufficiency, substantially increase the marketed product and therefore are possible only if the market is expanding, be it domestic or foreign.

As I am convinced that every farmer tries to improve his welfare and prosperity, he will always respond to an expansion of the market, if the infrastructure provides adequate marketing channels and he has the knowledge necessary for improvement of his production.

However it will always be his responsibility to take the decisions, to seize the opportunities presented to him and to choose whether to produce more or less for the market, on which depends whether he produces less or more of his own food. Price relationships between products and labour productivity will control his decisions. So price policy and subsidies may markedly influence those decisions (Joosten, 1960).

\section{The farmer's decisions}

Even the peasant farmer of farms classified in Group 2, whose monetary expenditures are chiefly land rent and casual labour, will reach a point, especially if tending towards Class 3 , where he faces external costs for inputs and has to relate the prices of those inputs to those of his products. If the farmer is striving for a higher prosperity, which he normally does up to a certain desired income, he must choose between several lines of action which will all increase his costs (Miracle, 1968): increase in farm area; intensification of land-use, meaning increase in the cropping rate (higher $R$ ), increase in the productivity of his land by using more labour and other inputs (e.g. fertilizers); and perhaps more capital assets. He must weight up these costs, often also his increased work and any risks against the expected prices for his produce, and any wages for working off the farm.

The literature contains many examples. To enumerate a few: intensive or extensive care of the cocoa enterprise on a farm against intensive or extensive care of the production of food crops (Galetti, et al., 1956); increase or decrease in rubber production against the growing of food crops (Joosten, 1960; Bauer, 1948), labour-saving methods by mechanization (Yang, 1965); less extensive cropping methods against the cost of hiring casual labour; increase or decrease in farm area against opportunities to earn additional income off the farm (Misawa, 1966).

So, during the course of commercializing his farm, the farmer is continually confronted by choices for the reallocation of his scarce resources and for the adjustments associated with these changing opportunities.

\section{Survey of other papers in this issue}

Research in agrarian economics is therefore focusing on these external and internal relations of input, output, welfare and leisure. This research is needed partly to understand the farmers' decisions in transition from traditional to commercial farming and especially to find how to inform the farmer and to help him in making better decisions. Mellor points to this need in his contribution to this special issue of this periodical.

Further development to commercial farming is promoted by increasing non-farm opportunities and by decreasing employment in the farming economy, as is most 
evident in Western Europe. It forces farming to become an industry, which uses all possible kinds of inputs. This can lead to an enormous increase in the productivity per unit area and to the need for a constantly increasing market. Whereas in a nearly traditional community one farm-family produces only enough for a quarter of a family outside the farm, in the Netherlands now the percentage of workers in farming has dropped to a tenth of the working population. Thus one farm serves 9 other families and even more when exports are allowed for.

In his contribution to this issue Maris shows the impact of such development on the farm business and some implications for farm size, management and price setting. Luning and Clayton describe some problems encountered in Surinam and East Africa. In analysing the causes underlying the transformation of family rice-farming in Surinam Luning shows that techno-economic factors are mainly responsible for differences in stages of development. As in many other areas of the world these factors were outside the individual farmer's control. Clayton in particular shows how in many cases choice decisions are made by the farmers, which at first sight may "appear to be irrational but in fact are not so once the scale of opportunity costs and the farmers objectives are taken into account, that the frequent divergence between technical and economic efficiency in peasant agriculture is due to the crucial role played by factor opportunity costs at the farm level".

Case studies by Edwards show that Jamaican farmers make decisions on two levels. Objectives in farming are different for the near and distant future. On Trinidad he finds that the nearness to markets creates a favourable environment for innovations.

Dantwala analyses the situation in India where agriculture is still mainly in Classes 2 and 3 (only a few in 4 and 5) with insufficient growth of the non-farm employment. There he advocates concentration of extension and other development efforts on those regions, where the conditions favour rational decision for an increase in prosperity.

\section{References}

Bachman, K. L. and Christensen, R. P., 1967. The economics of farm size in agriculture and economic growth. Southworth, H. M. and Johnston, B. F. (Eds). Ithaca (N.Y.).

Bauer, P. T., 1948. The rubber industry. London.

Boeke, J. H., 1953. Economics and economic policy of dual societies. New York.

Galetti, R., Baldwin, K. D .S. and Dina, I. O., 1956. Nigerian cocoa farmers. London.

Helleiner, G. K., 1966. Peasant agriculture, government and economic growth in Nigeria. Homewood (Ill.).

Joosten, J. H. L., 1960. Perverse supply curves in less developed economies? Neth. J. Agric. Sci., 8 (2).

Khusro, A. M., 1964. Returns to scale in Indian Agriculture. Indian J. Agric. Econ., nr. $3 / 4$.

Mellor, J. W., 1968. The function of agricultural prices in economic development. Indian J. Agric. Sci., Jan.

Miracle, M. P., 1968. Subsistance agriculture. Analytical problems and alternative concepts. $A m$. J. Agric. Econ., May.

Misawa, T., 1966. An analysis of the allocation of labour in part time farming. Rural Econ. Problems, May.

Tschajanov, A., 1923. Die Lehre von der bauerlichen Wirtschaft. Berlin.

Yang, W. Y., 1965. Methods of farm-management investigations. Rome. 